\title{
Traditional Mongolian Medicine - A Potential for Drug Discovery
}

\author{
Christa KLETTER * ${ }^{1}$, Sabine GLASL ${ }^{1}$, \\ Theresia THALHAMMER ${ }^{2}$, Samdan NARANTUYA ${ }^{3}$ \\ ${ }^{1}$ Department of Pharmacognosy, University of Vienna, \\ Althanstrasse 14, 1090 Vienna, Austria \\ ${ }^{2}$ Centre of Physiology and Pathophysiology, Medical University Vienna, \\ Waehringer Guertel 18-20, 1090 Vienna, Austria \\ ${ }^{3}$ Health Sciences University of Mongolia, Choidogiin Street 3, \\ Ulaanbaatar 48, P.O. Box 111, Mongolia
}

\begin{abstract}
The principles of Traditional Mongolian Medicine (TMM) and a short history of this medical tradition as practised in the Republic of Mongolia are provided. TMM represents an Asian medical tradition which is greatly influenced by Tibetan Buddhism and which had flourished for centuries in regions inhabited by the Mongols. After the communist ideology had gained recognition in Outer Mongolia in the early 20th century, an introduction of Western medicine and a decline of TMM could be observed. The revival of TMM in the Republic of Mongolia in the second half of the last century led to increasing scientific investigations in this ancient medical system in the country. Joint studies with foreign academic institutions followed. The co-operations of Mongolian academic institutions with Austrian Universities regarding research in traditionally used medicinal plants are discussed and results of joint scientific projects are presented.
\end{abstract}

\section{Key words}

Traditional Mongolian Medicine - Mongolian medicinal plants - Traditional Tibetan Medicine $\cdot$ Ethnopharmacognosy

* Corresponding author: Tel.: +43-1-4277-55244; Fax: +43-1-4277-9552.

E-mail: christa.kletter@univie.ac.at (C. Kletter). 


\section{Introduction}

Traditional healing methods of non-European societies, mainly of Asian origin, have become more popular in the West during the past decades. The spreading of knowledge about traditional medicines is due to various factors such as growing tourism, publicity in the worldwide web, traditional treatments applied by Asian physicians touring the West and the increasing demand of Western patients for alternative or complementary therapy. Traditional Chinese medicine (TCM), Ayurveda, Kampo and Traditional Tibetan Medicine represent the better known traditional systems. Rather unknown to the public is the traditional medicine of the Mongolian people. Based on Mongolian folk medicine, Traditional Mongolian Medicine had developed by replacing many shamanistic practices with medical theories, techniques and medication of Traditional Tibetan Medicine. The Mongolian medical system also integrated some aspects of other oriental medicines such as Ayurveda and Chinese medicine. Traditional Tibetan Medicine was introduced to the Mongols in the $16^{\text {th }}$ century when Lamaism became the leading religion. For centuries, Tibetan Buddhism had influenced the daily life and the religious practice of the Mongolians as well as the medical education of the Mongolian physicians. Monks were educated in traditional medicine in the monasteries and played an important role in the health system of the past. Medical disputations and the exchange of ideas between Mongolian and Tibetan doctors stimulated the development of the medical system on both sides. The term "emchi" which is used to address a traditional Tibetan as well as Mongolian physician is actually the Mongolian word for "medical doctor".

Today, the Mongolians live in different Asian countries and number around nine million. They inhabit mainly the territory of the Republic of Mongolia (the former Outer Mongolia), the Republic of China and Republics of the Russian Federation. 


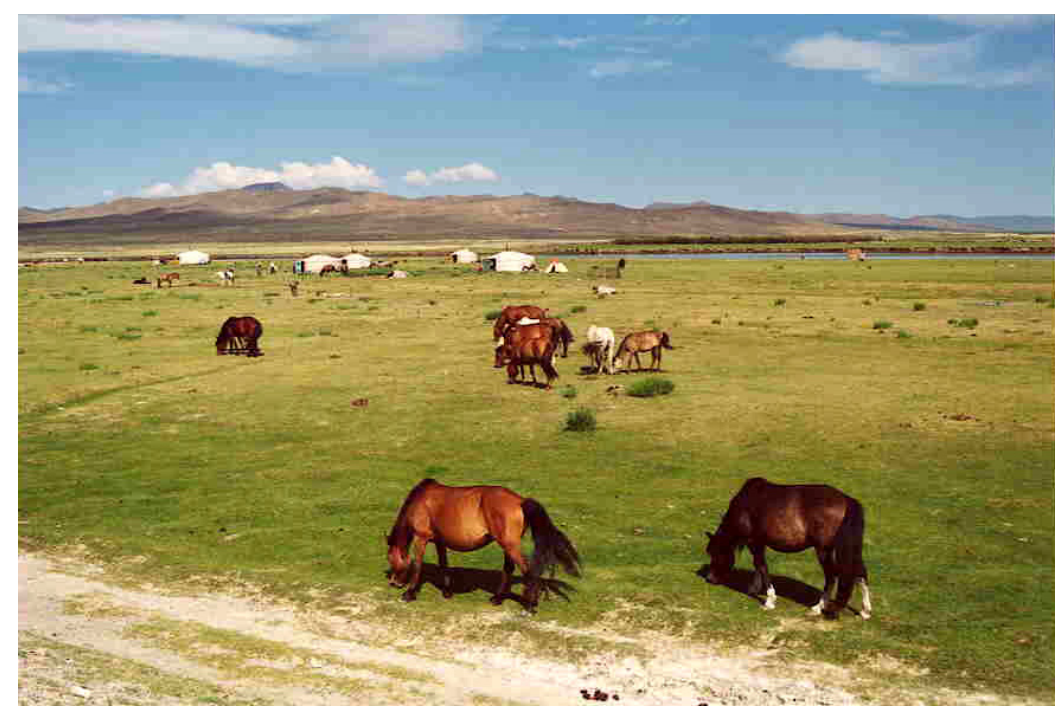

Fig. 1. Landscape in Central Mongolia with traditional nomadic dwellings

The Khalkha Mongols are the main ethnic group of the Republic of Mongolia representing almost $82 \%$ of the about 2.59 million inhabitants [1]. The Buryats are another large ethnic group of Mongolian descent, who live in Siberia, mainly in the Republic of Buryatia. They represent 436000 citizens of the Russian Federation [2]. In China, 5.8 million Mongols of different Mongolian ethnic groups are counted. The majority of those Mongolians, 3.5 million, live in the Inner Mongolia Autonomous Region [3].

\section{Traditional Medicine in the Republic of Mongolia}

In 1921 Mongolia declared independence from the Chinese supremacy and, in 1924, the Mongolian People's Revolutionary Party established the People's Republic of Mongolia. The communists of the neighbouring Soviet Union exerted great influence on Mongolian politics and, in 1936, the Mongolian republic entered into an alliance with the powerful neighbour. Treaties of friendship and cooperations were signed [4]. The Soviet communist influence in Mongolia caused dramatic changes in political and social structures. Lamaism, the religion which had dominated the people's life until the $20^{\text {th }}$ century, was banned officially. In 1937 , the destruction of monasteries and the persecution of monks had started and had led to a collapse of the religious institutions and subsequently also to the decay of the traditional medical system. Western medicine became the only permitted system 
and it was forbidden for long to practise the ancient Mongolian medicine. However, traditional medicine was still very popular and nearly everybody used it secretly, especially in cases of chronic diseases. Starting in 1959 some efforts were officially made to promote again traditional medicine and to initiate research in traditionally used medicinal plants and traditional medical concepts. After the political changes in the Soviet Union at the end of the last century, all restrictions on practising traditional medicine in the Republic of Mongolia were completely lifted. Traditional medicine had again become officially recognised as its own Mongolian medical heritage. After years of official banning it is now widely accepted in the Mongolian republic as an alternative or a complementary method to Western medicine and many patients are again treated by traditional methods and medication. Various hospitals and clinics apply Western as well as traditional methods for diagnosis and therapy. Many small clinics which offer traditional treatments have been established throughout the country within the last decade. Today, Traditional Mongolian Medicine is taught at various institutions situated in the republic's capital Ulaanbaatar. The School of Traditional Medicine of the Health Sciences University of Mongolia offers all degrees of education in traditional medicine and promotes research in this field. Other modern academic education centres of traditional medicine are the private colleges Manba Datsan and Monos Group.

\section{Principles of Traditional Mongolian Medicine}

The basics of Traditional Mongolian Medicine follow mainly the guidelines of Tibetan medicine and Tibetan Buddhism. There exists a great variety of ancient medical treatises written by Mongolian authors as well as Mongolian translations of renowned Tibetan medical books. Until today, Mongolian traditional doctors accept the main Tibetan medical treatise, the rgyud bzhi, as the basis of their medical knowledge. According to traditional medicine the human body is understood as an entity. Human health relies on the equilibrium of the three life-sustaining principles, named in Mongolian hii (Tibetan rlung), šar (Tibetan mkhris pa) and badgan (Tibetan bad kan). These terms are often translated into English as wind (hii), bile 
(šar) and phlegm (badgan), but they should not be confused with the same English terms used in antique Greek medicine. Any disturbance in the equilibrium of the three principles results in a disease. Therefore, re-establishing the equilibrium in the patient's body is the foremost task of the traditional physician. In general, hot and cold disorders are differentiated in Traditional Mongolian Medicine. To diagnose a disease the traditional physician reads the pulses, examines the tongue, checks the urine by smell, colour and taste and interrogates the patient. However, pulse reading is the main traditional diagnostic tool, because the physician checks the type of the disease (hot or cold) and the conditions of the internal organs in this way. He must be well experienced in recognising the healthy pulse in order to differentiate it from the pulse which indicates a specific disease [5]. Consequently, the traditionally diagnosed disorders do not easily match diseases as diagnosed by Western medicine. However, some symptoms listed in the traditional texts relate to Western disease syndromes.

The therapy of disease, according to traditional medicine, focuses first on changes in the patient's diet and behaviour in daily life. Other therapeutic measures are medication, massages, blood-letting, steam baths, drinking of mineral water, acupuncture and moxibustion. Moxibustion refers to a specific treatment. A cone made up of a powdered plant is stuck to a specific point of the body. Then, the cone is lightened to burn down slowly warming up the respective part of the body. The medical preparations used to cure the disorders are complex mixtures of a varying number of ingredients, mainly plants, but they contain also minerals and animal drugs such as musk or sheep's liver. In general, one ingredient of a medicine is always specified as the leading one while the remaining ones support the main ingredient in its efficacy. A specific nature (cooling, warming and neutral) and particular qualities and secondary qualities which influence the three life-sustaining principles in the body are assigned to each ingredient (Table 1). 
Tab. 1. Taste, property, qualities and secondary qualities of medicinal plants according to Traditional Mongolian Medicine

\begin{tabular}{|c|c|c|c|c|}
\hline Plant Species / Family & Taste & Property & Quality & $\begin{array}{c}\text { Secondary } \\
\text { Quality }\end{array}$ \\
\hline \multirow{3}{*}{$\begin{array}{l}\text { Dianthus versicolor Fisch./ } \\
\text { Caryophyllaceae }\end{array}$} & \multirow[b]{3}{*}{ bitter } & \multirow[b]{3}{*}{ cooling } & \multirow[b]{3}{*}{ cool } & coarse \\
\hline & & & & blunt \\
\hline & & & & light \\
\hline \multirow{2}{*}{$\begin{array}{l}\text { Gentiana barbata Froel./ } \\
\text { Gentianaceae }\end{array}$} & \multirow[b]{2}{*}{ bitter } & \multirow[b]{2}{*}{ cooling } & \multirow[b]{2}{*}{ cool } & coarse \\
\hline & & & & blunt \\
\hline \multirow{3}{*}{$\begin{array}{l}\text { Gentiana decumbens L. f./ } \\
\text { Gentianaceae }\end{array}$} & \multirow{3}{*}{$\begin{array}{l}\text { bitter, } \\
\text { astringent }\end{array}$} & \multirow[b]{3}{*}{ cooling } & \multirow[b]{3}{*}{ cool } & smooth \\
\hline & & & & flexible \\
\hline & & & & fluidity \\
\hline $\begin{array}{l}\text { Lilum pumilum DC.I } \\
\text { Liliaceae }\end{array}$ & sweet & cooling & cool & cool \\
\hline \multirow{2}{*}{$\begin{array}{l}\text { Myricaria longifolia Ehrenb./ } \\
\text { Tamaricaceae }\end{array}$} & \multirow{2}{*}{$\begin{array}{l}\text { astringent, } \\
\text { bitter }\end{array}$} & \multirow[b]{2}{*}{ cooling } & cool & heavy \\
\hline & & & blunt & stable \\
\hline \multirow{2}{*}{$\begin{array}{l}\text { Saussurea amara L. (DC)/ } \\
\text { Asteraceae }\end{array}$} & \multirow[b]{2}{*}{ bitter } & \multirow[b]{2}{*}{ cooling } & \multirow[b]{2}{*}{ light } & coarse \\
\hline & & & & blunt \\
\hline
\end{tabular}

In general, hot diseases are treated with medicines having mainly a cooling nature, while cold diseases require a treatment with medicines of a warming nature. The efficacy of a medicinal product greatly depends on the proper blending of the ingredients according to their inherent qualities in order to achieve a stimulation of the healing process. A hot disease requires another blending of the ingredient's qualities than a cold disease. Therefore, it is very important that the qualities and secondary qualities of the ingredients are well-balanced, because otherwise the medicine may exert an adverse effect on the patient instead of a favourable one.

In the past the traditional physician collected the necessary plants, minerals and animal products for his medication on his own in his living area and bought missing drugs at the markets, sometimes in distant places. The basic information about medication and the characteristics for identifying the plants, minerals and animal drugs is found in the traditional medical texts. However, to identify the ingredients the physicians rely on different oral traditions and written documentaries 
laid down by renowned scholars of the past. Consequently, differences in the identification of the plants, animal drugs and minerals produce different ingredients. Moreover, regarding plants, differences in the vegetation of different collection areas lead to the harvesting of different plant species. Therefore, the same Mongolian plant name may stand for more than one species and different plants may be collected under the same traditional name. In the past, each traditional physician prepared the medicine for his patients himself according to the prescriptions of the medical texts or his own experiences. Today, the mode of preparing medicines has greatly changed. A large amount of the traditional medicines is now produced in the big centres of traditional medicine as well as by Mongolian companies using modern production methods. The needed plants, animal drugs and minerals are collected by the locals in the Mongolian countryside or the ingredients are purchased at various markets in and outside Mongolia. Such prefabricated traditional medicines are sold within the Republic of Mongolia, some of the products are even exported. Legal regulations are issued to control drug identity, efficacy and safety.

\section{Research in Plants of Traditional Mongolian Medicine}

Traditional medicine plays again an important role in the Mongolian health system and methods of natural science are applied to investigate this ancient medical system and to prove the efficacy of the therapeutic methods and the traditional medication. In the past Mongolia maintained close connexions to the socialist countries, mainly to the former Soviet Union, and collaborated in all fields of science. For many years the Mongolians have been substantially supported by its potent neighbour but the financial support dwindled after the breakdown of the communist system in the former Soviet Union. Such loss of financial means led to a setback in the Mongolian research activities and new collaborations with other Asian countries and Western universities and academies were sought. Among the new academic partners were also various universities in Austria. One of these new partners was the Department of Pharmacognosy, University of Vienna. 
In 1998 the contact between the Department of Pharmacognosy and Mongolia was initiated by Samdan Narantuya, at that time researcher in the Institute of Chemistry and Chemical Technology, Mongolian Academy of Sciences, who stayed several months in the institute to do chemical research on Mongolian Achillea species. At the same time an interdisciplinary project regarding plants used in Traditional Tibetan Medicine was conducted in the institute [6]. Due to the similarities between Tibetan and Mongolian Traditional Medicine, the research of traditionally used Mongolian plants was a promising scientific task. Information about Mongolian plants in the West was scarce, because most publications were written in Mongolian or Russian language and many scientific articles were published in inaccessible Mongolian or Russian journals. Only two books about traditionally used Mongolian plants have been published in English so far [7, 8]. Such books present mainly compilations of plant names, some of them cite traditional names and, in addition, the corresponding scientific names. More botanical information about medicinal plants growing in Mongolia can be found in one Russian monograph which was translated into English only some years ago [9].

At the beginning of the Austrian-Mongolian cooperation the investigations concentrated mainly on chemical studies of several Achillea species. New compounds could be isolated and their chemical structures were elucidated [10, 11, $12,13,14]$. In collaboration with the Health Sciences University of Mongolia, the Mongolian Academy of Sciences and Manba Datsan, a private centre of traditional medicine in Ulaanbaatar, the Department of Pharmacognosy started a joint project in 2001 regarding the botanical identity of Mongolian plants, their content of bioactive compounds and therapeutic efficacy [15]. The research focussed on plants used for the traditional treatment of liver disorders. Impairment of the liver is very common in Mongolia and, according to the National Statistical Office of Mongolia, liver cancer, viral hepatitis, liver and gastrointestinal disturbances are increasingly monitored in the Mongolian population. Alcohol abuse and the Mongolian habit to consume meat as staple diet favour the outbreak of such 
diseases. As mentioned before, traditional methods of diagnosis do not necessarily correlate with diseases as classified in Western medicine. In Traditional Mongolian Medicine, there are, in general, hot and cold disorders; regarding liver impairment, there are 13 hot disorders and 5 cold ones. However, some symptoms listed in the traditional texts relate to Western disease syndromes. For example, regarding liver disorders, the traditional texts mention fever, localisation of pain or yellow skin, symptoms which indicate a liver involvement.

For our investigations we chose plants which are most frequently used in the traditional therapy of liver disorders (Table 1). The plant specimens were collected in joint expeditions with the Mongolian partners in various regions of Mongolia and taken to Austria for botanical, chemical and pharmacological investigations. In Austria, botanical-anatomical and chemical analyses of the plant material were carried out to elaborate a protocol for quality control for each plant species. Such protocols include instructions how to check the identity and purity of the chopped and powdered plant material in order to verify the quality of any plant sample which is collected at a later date [16]. Several plants - Dianthus versicolor FISCH., Gentiana barbata FROEL., Myricaria longifolia EHRENB. and Saussurea amara L. (DC) underwent further chemical analyses and new compounds could be isolated and their structures elucidated $[17,18,19,20]$.

The medical application of specific plants for long periods, e.g. in traditional medicines, suggests the presence of biologically active substances in those plant species. Therefore, the main aspect of the study focussed on the finding of the plants' bioactive compounds by means of bio-assay-guided fractionation. The plants of our study belong to plant families which are well-known sources for medicinal plants, but the selected Mongolian species are, in general, scarcely investigated and only few studies exist about their efficacy. For example, the aqueous extracts of Gentiana barbata [21] and G. decumbens L.f. [22] showed a free radical scavenging action, and, in another study, an immunomodulant activity was found for gentiabavaroside, a secondary metabolite of Gentiana barbata [23]. 


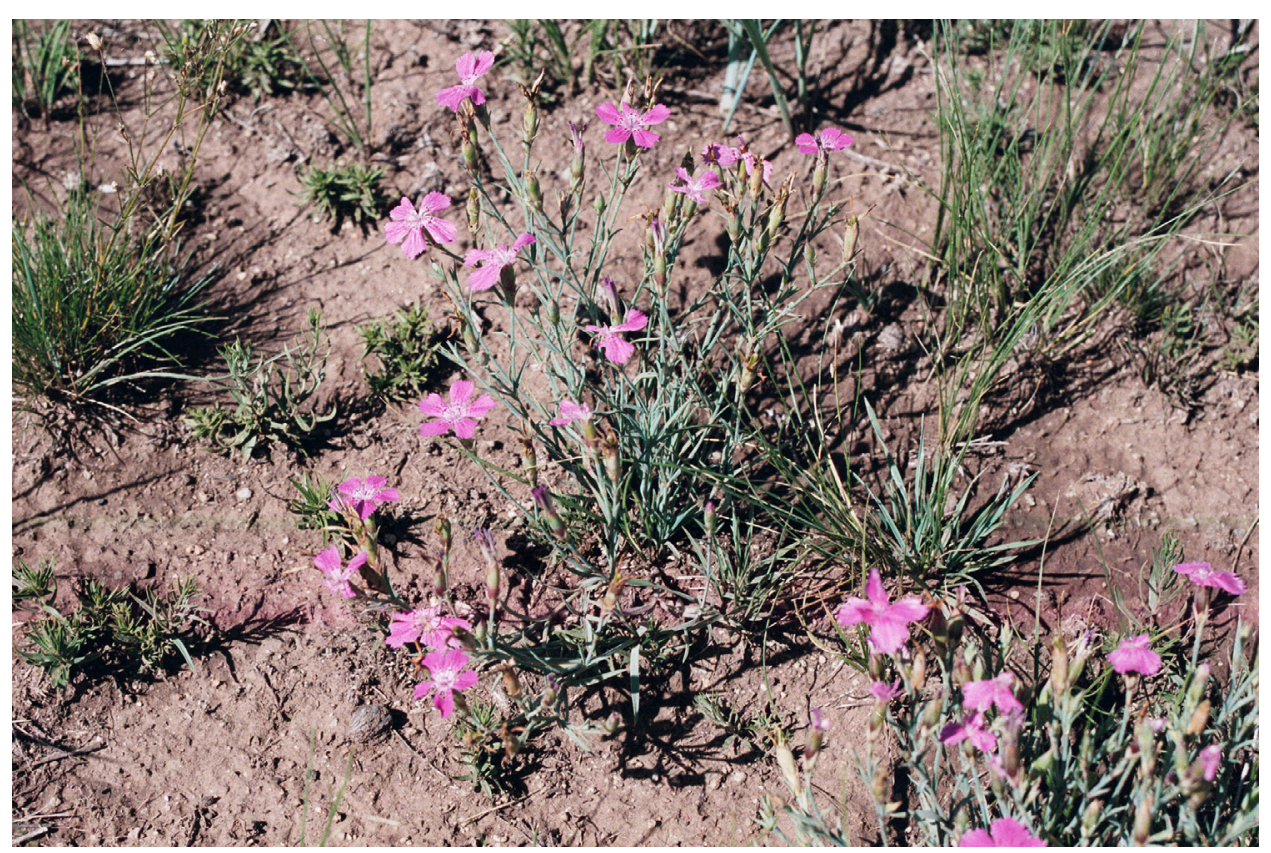

Fig. 2. Dianthus versicolor FISCH.

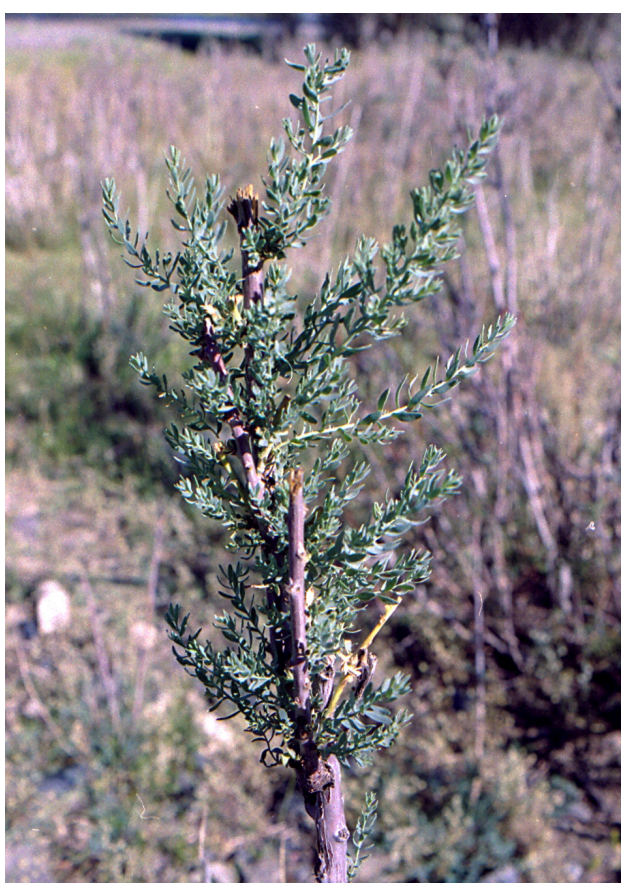

Fig. 3. Myricaria longifolia EHRENB.

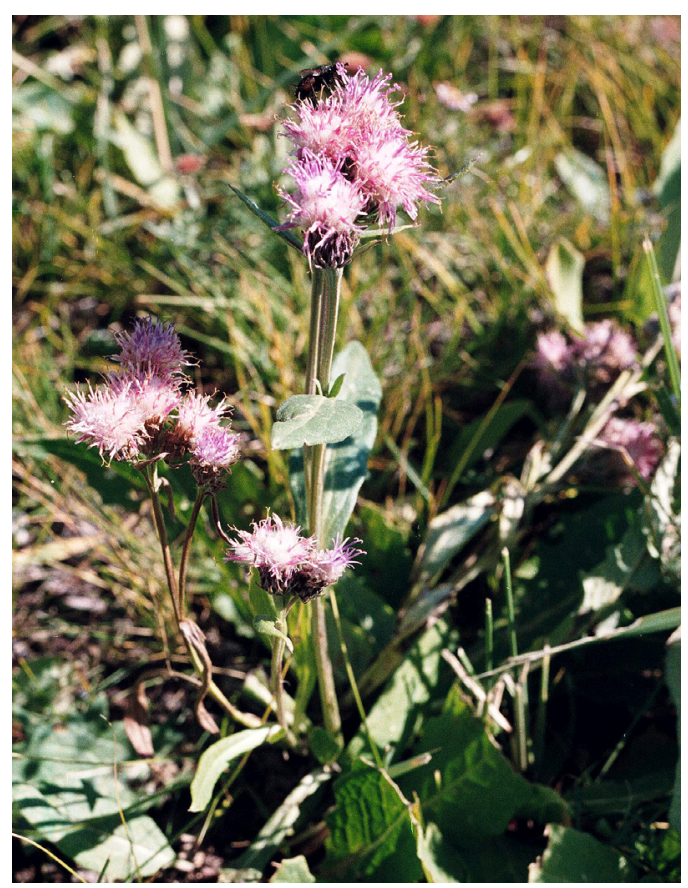

Fig. 4. Saussurea amara L. (DC) 
Sesquiterpenes with neoplasm-inhibiting and bactericidal acitivity were found in Saussurea amara extracts [24, 25].

The first biological screenings focussed on plants with potential bile-flowstimulating effects, which might be useful in treating impairments in the hepatobiliary system. A variety of digestive problems including discomfort in the stomach, bloating, lack of appetite, nausea and mild diarrhoea or constipation may be improved by the intake of choleretic compounds which effectively stimulate bile secretion. Plant extracts and pure substances were tested for their potential to stimulate bile secretion (choleresis) in the isolated rat liver perfusion system. The results of those screenings showed that extracts of Lilium pumilum DC and Saussurea amara enhanced the bile secretion [26]. The sesquiterpene cynaropicrin and the flavonoid apigenin-7-O-glucoside could be detected as the bile secretion stimulating compounds of Saussurea amara extracts [27].

Other investigations focussed on toxicological properties of the plants to study. The aqueous extracts of Dianthus versicolor, Gentiana barbata, Lilium pumilum and Myricaria longifolia were examined for their biological effects on primary rat hepatocytes. Only Myricaria longifolia extracts exerted a pronounced cytotoxic effect inducing necrosis [28]. The presence of cytotoxic compounds in Myricaria longifolia might explain the inhibiting effect of Myricaria extracts on the bile flow in the isolated rat liver perfusion system. None of the tested extracts showed a genotoxic effect [28].

Our studies of traditionally used Mongolian plants have not been finished yet, but the phytochemical investigations and the results of the bioassays having been achieved to date seem to provide a rational approach for their traditional use.

\section{References}

[1] Mongolian National Statistical Office (NSO), Main Results, Population and Housing Census, 2000.

[2] http://en.wikipedia.org/wiki/Buryats, accessed 22.11.2007.

[3] http//:www.china.org.cn/english/features/EthnicGroups/136937.htm, accessed 11.11.2007. 
[4] Stearns P N, et al. editors.

The Republic of Mongolia (The Mongolian People's Republic).

In: The Encylopedia of World History, 1945-2000, 6.ed. Houghton Mifflin Company, Boston, 2001.

http://www.bartleby.com/67/4187.html, accessed 31.8.2007.

[5] Bold S, Ambaga M.

History and fundamentals of Mongolian Traditonal Medicine.

Ulaanbatar, Mongolia, 2002.

[6] Kletter Ch, Kriechbaum M, editors.

Tibetan medicinal plants.

Authors: Ch. Kletter, M. Kriechbaum, R. Krasser, D. Dawa, D. Dekhang, W. Holzner.

Medpharm. scientific publishers, Stuttgart, CRC Press, Boca Raton, London, New York, Washington DC., 2001.

[7] Ligga U.

Medicinal plants of Mongolia used in Mongolian traditional medicine.

KCA Press, Korea, 1994.

[8] Boldsaikhan B.

Encyclopedia of Mongolian medicinal plants.

Vol. $1,2^{\text {nd }}$ ed., Mongolian University of Science \& Technology, System

Science Research Institute, Ulaanbaatar, 2004.

[9] Grubov V I.

Key to the vascular plants of Mongolia.

Enfield (NH), USA, Plymouth, UK: Science Publishers, Inc., 2001.

[10] GlasI S, Presser A, Gunbilig D, Werner I, Narantuya S, Haslinger E, Jurenitsch J, Kubelka W.

Highly hydroxylated guaianolides of Achillea asiatica and Middleeuropean

Achillea species.

Phytochemistry. 2001; 58: 1189-1194.

[doi:10.1016/S0031-9422(01)00281-3]

[11] GlasI S, Gunbilig D, Narantuya S, Werner I, Jurenitsch J.

Combination of chromatographic and spectroscopic methods for the isolation and characterization of polar guaianolides from Achillea asiatica.

J Chromatogr A. 2001; 935: 193-200.

[doi:10.1016/S0021-9673(01)00947-5]

[12] Narantuya S, GlasI S, Batsuren D, Jurenitsch J.

On the investigations of Mongolian Achillea species.

Sci Pharm. 1999, 67: 69-76. 
[13] Narantuya S, GlasI S, Presser A, Werner I, Haslinger E, Jurenitsch J, Kubelka W.

A new proazulene of Achillea asiatica.

47th Congress of the Society for Medicinal Plant Research; 26.-30.7. 1999, Amsterdam.

Abstract Book. 1999: 244.

[14] Narantuya S, Byambajav Ts, Myagmar L, Kletter Ch, Kubelka W.

Coumarins of the aerial parts of Stellera chamaejasme and their woundhealing activity.

$6^{\text {th }}$ International Congress on Ethnopharmacology and 48th Annual Meeting of the Society for Medicinal Plant Research, 3.9-7.9.2000, Zürich.

Abstract Book. 2000: P3B/13.

[15] Kletter Ch.

Interdisciplinary and Intercultural Austrian Projects on Tibetan and Mongolian Medicine.

Viennese Ethnomedicine Newsletter. 2003; 5: 7-12.

[16] Kletter Ch, Nyambayar D, Ganbold E, Narantuya S, Natsagdorj D.

Quality control of plants used in traditional Mongolian medicine.

$9^{\text {th }}$ International Congress of Ethnobiology, in collaboration with the $45^{\text {th }}$

Annual Meeting of the Society for Economic Botany and the $8^{\text {th }}$ International

Congress of Ethnopharmacology 13.6.-17.6.2004, University of Kent,

Canterbury.

Abstract Book. 2004: A60.

[17] Obmann A, Radovic T, Kletter Ch, Glasl S.

HPLC-MS-analysis of flavonoid-C-glycosides in the Mongolian medicinal plant

Dianthus versicolor.

55th Annual Meeting of the Society for Medicinal Plant Research; 2.9.-

6.9.2007, Graz.

Planta Med. 2007; 73: 931, P346.

[doi:10.1055/s-2007-987126]

[18] Glasl S, Mayr K, Daariimaa K, Narantuya S, Kletter Ch.

Phytochemical investigation of the Mongolian medicinal plant Saussurea amara (L.) DC (Asteraceae).

54th Annual Meeting of the Society for Medicinal Plant Research; 29.8.-

2.9.2006, Helsinki.

Planta Med. 2006; 72: 1000, P056.

[doi:10.1055/s-2006-949856] 
[19] Donath O, GlasI S, Kletter Ch, Narantuya S.

Phytochemical investigation of Myricaria longifolia - a plant used in traditional Mongolian medicine.

19th Annual Scientific Meeting of the Austrian Pharmaceutical Society, 20.22.4.2006, Innsbruck.

Sci Pharm. 2006; 74: S93.

[20] Purevsuren S, Glasl S, Kletter Ch, Presser A, Narantuya S.

Phytochemical investigation of Gentiana barbata Froel. - a plant used in traditional Mongolian medicine.

19th Annual Scientific Meeting of the Austrian Pharmaceutical Society, 20.22.4.2006, Innsbruck.

Sci Pharm. 2006; 74: S97.

[21] Nikolaev S M.

Experimental antioxidant pharmacotherapy of liver injuries.

Farmakologiia I Toksikologiia. 1983; 46: 79-81. Abstract.

[22] Myagmar B E, Aniya Y.

Free radical scavenging action of medicinal herbs from Mongolia.

Phytomedicine. 2000; 7: 221-229.

[23] Nikolaeva G G, Sergeev A V, Nikolaev S M, Glyzin V I, Dargaeva T D, Sambueva Z G, Tsyrenzhapov A V.

Isolation and immunomodulant activity of gentiabavaroside from Gentiana barbata.

Pharm Chem J. 2004; 38: 25-27.

[doi:10.1023/B:PHAC.0000027640.83324.cd]

[24] Konovalova O A, Rybalko K S, Pimenov M G.

Sesquiterpene lactone from Saussurea amara.

Khim Prir Soed. 1979; 6: 865-866.

Chem Nat Comp. 1980; 15: 773.

[doi:10.1007/BF00565603]

[25] Modonova L D, Semenov A A, Zhapova T S, Ivanova N D, Dzhaparova A K, Fedoseev A P, Kirdei E G, Malkova T I.

Biological activity of Saussurea amara.

Khim-Farm Zh. 1986; 20: 1472-1475.

[26] Kletter Ch, Thalhammer Th, Tsendayush D, Glasl S, Gunbilig D, Nyambayar D, Ganbold E, Narantuya S.

Investigations of plants used in traditional Mongolian medicine for the treatment of liver disorders.

Traditional medicine: Current situtation and the future status, International Conference of Mongolian Traditional Medicine, 15-17.9.2004, Ulaanbaatar. Abstract book. 2004: 18. 
[27] Glasl S, Tsendayush D, Batchimeg U, Holec N, Wurm E, Kletter Ch, Gunbilig D, Daariimaa Kh., Narantuya S, Thalhammer Th.

Choleretic effects of the Mongolian medicinal plant Saussurea amara (Asteraceae) in the isolated perfused rat liver.

Planta Med. 2007; 73: 59-66.

[doi:10.1055/s-2006-957063]

[28] Vogl C, Krencker D, Bresgen N,. Eckl PM, Glasl S, Kletter Ch.

In vitro toxicological properties of selected Mongolian traditional medicinal plants.

50 Years of the Phytochemical Society of Europe; 11.-14.4.2007, Cambridge. Abstract Book. 2007: P176. 